\title{
Nauplius
}

The Journal of The

Brazilian Crustacean Society

This article is part of the tribute offered

by the Brazilian Crustacean Society

in memoriam of Michael Türkay for his

e-ISSN 2358-2936

www.scielo.br/nau www.crustacea.org.br

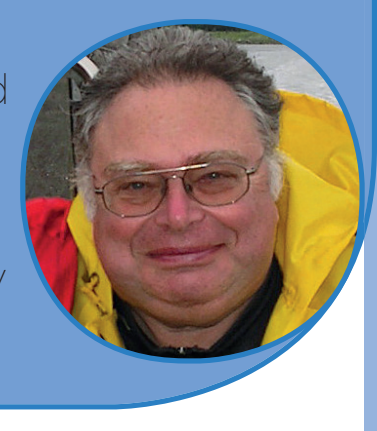

Original Article

\section{Designation of a new genus Michaelimenes (Decapoda: Caridea: Palaemonidae), with new host record and range extension of its type species, M. perlucidus (Bruce, 1969)}

\author{
Junji Okuno ${ }^{1}$ \\ ${ }^{1}$ Coastal Branch of Natural History Museum and Institute, Chiba, 123 Yoshio, \\ Katsuura, Chiba 299-5242, Japan \\ ZOOBANK http://zoobank.org/urn:lsid:zoobank.org:pub:3FAF9B90-0A17-43C3- \\ 8E75-636B08CCDC91
}

\begin{abstract}
A new palaemonid shrimp genus, Michaelimenes n. gen., is established for three Indo-West Pacific species, Periclimenes latipollex Kemp, 1922, Periclimenes perlucidus Bruce, 1969 (type species) and Periclimenes platydactylus Li, 2008. The present new genus can be immediately distinguished from other related genera by the combination of the second pereiopod with the dorsal flange on the dactylus, the proximal excavation on the fixed finger and the smooth propodus, and the unarmed, non-subspatulate fingers of the first pereiopod. The type species, Michaelimenes perlucidus, is recorded from Japan for the first time on the basis of 34 specimens associated with the alcyonacean genus Chironephthya Studer, 1887. The intraspecific morphological variation and host specificity of $M$. perlucidus are commented upon. Periclimenes involens Bruce, 1996 is regarded as a junior synonym of M. perlucidus.
\end{abstract}

CORRESPONDING AUTHOR Junji Okuno

okuno@chiba-muse.or.jp

SUBMITTED 4 January 2017

ACCEPTED 15 February 2017

PUBLISHED 8 May 2017

Guest Editor

Célio Magalhães

DOI 10.1590/2358-2936e2017013

KeY WORDS

Crustacea, descriptive taxonomy, Indo-West Pacific, Periclimenes. 


\section{INTRODUCTION}

Shrimps of the palaemonid genus Periclimenes Costa, 1844 are chiefly associated with various taxa of marine invertebrates and distributed from the intertidal to deep sea waters worldwide except for the higher latitudinal regions. Within marine palaemonid shrimps, it is the most species-rich genus comprising over 150 species (De Grave and Fransen, 2011). However, Gan et al. (2015) and Horká et al. (2016) suggested that Periclimenes is a polyphyletic taxon on the basis of molecular evidence. High morphological diversity is also shown within the genus, and Periclimenes is divided into some species groups, for instance, Periclimenes obscurus Kemp, 1922, Periclimenes diversipes Kemp, 1922, and Periclimenes iridescens Lebour, 1949 (Bruce, 1989; De Grave and Anker, 2009; Eilbracht and Fransen, 2015). Furthermore, there are numerous Periclimenes species not included in any species group. Recent taxonomic studies dealing with Periclimenes have removed many species to other genera (e. g., Okuno and Bruce, 2010, and Ďuriš and Horká, 2017 for cnidarian associates; Marin and Chan, 2014, and Duriš and Horká, 2017 for echinoderm associates; Kou et al., 2016 for deep sea species), and several remaining species of Periclimenes should be taxonomically reevaluated with regards to their generic position.

One of the species of Periclimenes not included in any species group, Periclimenes perlucidus, was originally described by Bruce (1969) on the basis of a single ovigerous female from the South China Sea. The original description is detailed but without any illustration. The fully illustrated detailed redescription of the species by the original author was based on numerous specimens from Madagascar, western Indian Ocean (Bruce, 1978a). During a survey of the Japanese caridean shrimp fauna, over 30 individuals referred to $P$. perlucidus associated with the octocorallian soft corals of Chironephthya spp. (Alcyonacea: Nidaliidae) were captured from warm temperate to subtropical regions of the country. Careful examination on the specimens from Japanese waters revealed that $P$. perlucidus should be elevated to full generic status on account of the unusual structure on the dactylus and fixed finger of the second pereiopod. Herein, I establish a new genus, Michaelimenes for P. perlucidus, and consider $P$. latipollex Kemp, 1922 and P. platydactylus Li, 2008 as congeneric. Furthermore, Periclimenes involens Bruce,
1996 is regarded a junior synonym of M. perlucidus in the present study.

\section{Material and Methods}

The specimens examined herein were directly captured from the host colonies of alcyonaceans by diving. The illustrations were made with a drawing tube mounted on a LEICA MZ12 stereomicroscope. The postorbital carapace length is abbreviated as $\mathrm{CL}$ in the text. The specimens examined in this study are deposited in the Coastal Branch of Natural History Museum and Institute, Chiba (CMNH), and Naturalis Biodiversity Center (former Rijksmuseum van Natuurlijke Histoire), Leiden (RMNH).

\section{Systematics}

\section{Family Palaemonidae Rafinesque, 1815}

\section{Michaelimenes n. gen.}

Type species. Periclimenes perlucidus Bruce, 1969; by present designation.

Etymology. The present new genus is named in honor of the late Dr. Michael Türkay (1948-2015) for his great contributions to the systematics of various groups of decapod crustaceans from all over the world, combined with part of Periclimenes. Gender: masculine.

Diagnosis. Small sized palaemonid shrimp with subcylindrical, slender body form. Carapace smooth, glabrous, antennal and fixed hepatic spines present, orbit feebly developed, inferior orbital angle produced, without reflected inner ventral flange, pterygostomial margin rounded, feebly produced. Rostrum well developed, horizontal, ventral margin straight, dorsally and ventrally dentate, lateral carina obsolete. Ophthalmic somite without interocular beak. Fourth thoracic sternite without acute median process. Abdomen smooth, third tergite non-carinate or posteriorly produced, pleura of fourth and fifth segments posteroventrally produced, rounded. Telson slightly longer than sixth abdominal somite, gradually tapering distally, with two pairs of dorsolateral spines, posterior margin with three pairs of spines. Eyes with well developed globular cornea. Antennule normally 
developed. Antenna with basicerite armed distolaterally with a single acute tooth, without dorsal angular process, scaphocerite well developed. Epistome without horn-like process. Mandible without palp, molar and incisor processes normal. Maxillula with bilobed palp, upper and lower laciniae well developed. Maxilla with normal palp, distal endite bifid, proximal endite feebly produced, scaphognathite broad. Maxillipeds with slender exopodal flagella. First maxilliped with caridean lobe large, epipod triangular. Second maxilliped with epipod oval, without podobranch. Third maxilliped with coxal plate large, subquadrate; arthrobranch small. First pereiopod slender, with dactylus normal, not subspatulate, fingers with cutting edges unarmed. Second pereiopods smooth, glabrous, equal or unequal in length and shape. Major second pereiopod with carpus short, slightly widended distally; palm elongate, subcylindrical, entire; fixed finger with proximal excavation on the cutting surface, for the reception of proximal part of dactylar cutting edge when both fingers closed, dactylus short, dorsally with developed flange, cutting edge dentate proximally. Minor second pereiopod with carpus short or elongate; palm subcylindrical, entire; fixed finger with proximal excavation similar to major pereiopod, dorsomesial flange of dactylus distinct or obsolete. Ambulatory pereiopods slender, meri unarmed, propodi armed with ventral spines, but without transverse rows of tufts of dense setae, dactyli with distoventral tooth on corpus small or lacking. Male first pleopod with endopod distally rounded, mesially with slender or angular process. Male second pleopod with endopod with appendix interna longer than appendix masculina.

Species included. Periclimenes latipollex Kemp, 1922, Periclimenes perlucidus Bruce, 1969 (type species) and Periclimenes platydactylus Li, 2008.

Common name. Yaiba-kakure-ebi zoku (new standard Japanese name).

Remarks. Michaelimenes is discriminated from other allied genera by the combination of having the fingers of the first pereiopod unarmed and non-subspatulate (Fig. 1A), the second pereiopod with a smooth palm, a proximal excavation on the cutting surface of the fixed finger (Fig. 1B, E) and a dorsal flange on the dactylus
(Fig. 1C, D), the straight and horizontal rostrum dorsally and ventrally dentate (Fig. 3A), and the feebly developed orbit (Fig. 3A). It is noteworthy that the proximal excavation on the second pereiopodal fixed finger assumes the reception to the dactylar proximal cutting edge when the fingers closed (Fig. 1D), therefore, the dactylus and fixed finger slide against each other along both proximal cutting edges. In most of shrimps belonging to the genus Periclimenes and its related genera, the cutting edges coincide each other. Furthermore, the distal edge of the fixed finger fits in the oblique mesial surface ventrad to the dorsal flange of the dactylus and thus, the gape does not occur between the completely closed fingers. This unusual structure distinguishes Michaelimenes from the genus Periclimenes, as typified by its type species, P. amethysteus (Risso, 1826) (see Grippa and Udekem d'Acoz, 1996), and other congeneric species as generic rank except for P. latipollex and P. platydactylus.

Periclimenes latipollex was originally described by Kemp (1922) on the basis of three specimens from the Mergui Archipelago, eastern Indian Ocean. It has been additionally recorded from the depths of 73-440 $\mathrm{m}$ at Somalia, Kenya, Philippines, Indonesia, New Caledonia and Japan (Hayashi, 2005; Li and Bruce, 2006). Kemp (1922) mentioned that the positional relation between the dactylus and fixed finger of the second pereiopod in P. latipollex resembles that of the blades of scissors, and Bruce (1991) illustrated this structure. Since this diagnostic character links $P$. latipollex with $M$. perlucidus, this species should also be considered as a member of Michaelimenes.

Li (2008) originally described P. platydactylus on the basis of the single ovigerous female holotype from a depth of 108-112 $\mathrm{m}$ at the Marquesas Islands in French Polynesia. At that time, P. platydactylus was compared with the Periclimenes alcocki Kemp, 1922 species group (now considered as the separate genus under the name of Bathymenes Kou, Li and Bruce, 2016). The similarity between $P$. platydactylus and $P$. perlucidus was not alluded to the original description, although these two species share the flange on the dactylus and proximal excavation on the fixed fineger of the second pereiopod. Herein, I regard the two species as congeneric, and place P. platydactylus into Michaelimenes. 


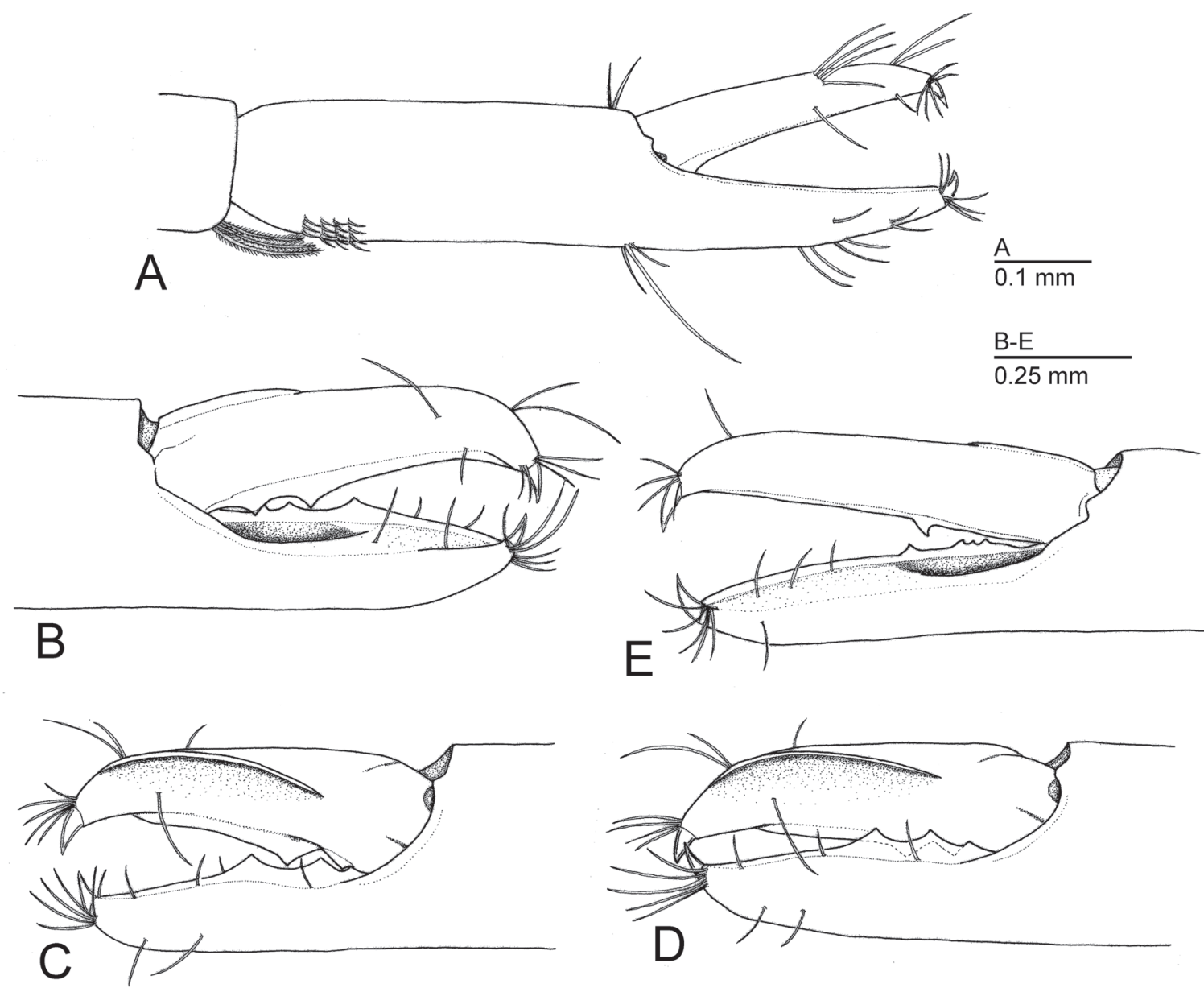

Figure 1. Diagnostic morphological features of Michaelimenes n. gen. based on the type species, M. perlucidus (Bruce, 1969), n. comb. Male, CL 1.6 mm (CMNH-ZC 02526) (A-D); ovigerous female, CL $2.3 \mathrm{~mm}$ (CMNH-ZC 02528) (E). A, right first pereiopod, distal part of carpus and chela, lateral; B, fingers of right major second pereiopod, lateral; C, same, mesial; D, same, weakly closed, mesial; E, fingers of left minor second pereiopod, lateral.

In general morphology, P. latipollex, P. perlucidus and P. platydactylus also share the straight and horizontal rostrum with both margins dentate, and the feebly developed orbit. The differences among these congeneric species are summarized in the following key.

\section{Key to the species of Michaelimenes $\mathbf{n}$. gen.}

1. Rostrum styliform, more than 2 rostral dorsal teeth situated posterior to posterior orbital margin; distolateral tooth of scaphocerite reaching distal margin of lamella ........................ M. latipollex (Kemp, 1922) n. comb.

-. Rostrum not styliform, 0-1 rostral dorsal tooth situated posterior to posterior orbital margin; distolateral tooth of scaphocerite falling clearly short of distal margin of lamella

2. Rostral lateral carina obsolete; second pereiopods distinctly unequal in length, dissimilar in shape, minor pereiopod with flange of dactylus feeble, carpus elongate; ambulatory dactyli stout, biunguiculate

M. perlucidus (Bruce, 1969) n. comb.

-. Rostral lateral carina proximally distinct; second pereiopods slightly unequal in length, similar in shape, minor pereiopod with flange of dactylus developed, carpus short; ambulatory dactyli slender, simple (except for left third pereiopod with minute accessory tooth) M. platydactylus (Li, 2008) n. comb. 


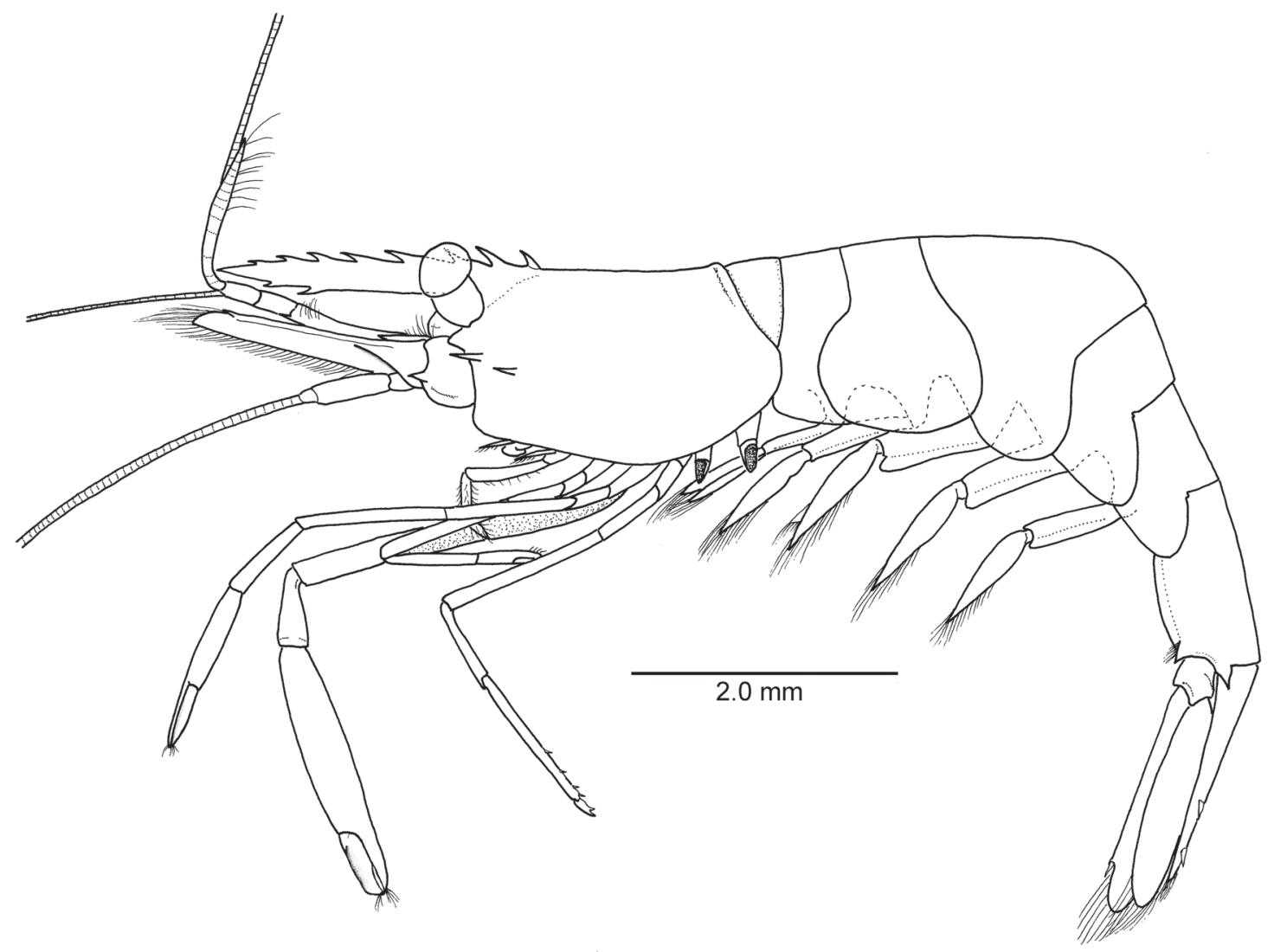

Figure 2. Michaelimenes perlucidus (Bruce, 1969), n. comb. Male, CL $1.6 \mathrm{~mm}$ (CMNH-ZC 02526). Entire animal, lateral.

Two species from the Indo-West Pacific, Periclimenes carinidactylus Bruce, 1969 and Periclimenes compressus Borradaile, 1915, one from the Eastern Pacific, Periclimenes infraspinis (Rathbun, 1902), and one from the north-western Atlantic, Periclimenes tenellus (Smith, 1882) also have a dorsal flange on the dactylus of the second pereiopod (Holthuis, 1951; Bruce, 1978b, 1980). From the literature, however, the presence of the excavation on the proximal part of cutting surface of the fixed finger and the occurrence of the sliding cutting edges of both fingers (see Fig. 1D) are not recognized in these species. Therefore, they should remain in Periclimenes, and the generic position of them should be determined in future works with the investigation on the exact specimens.

Periclimenes forcipulatus Bruce, 1991, known only from deep water of the Loyalty Islands, is similar to Michaelimenes in the structure of the fingers of the second pereiopod, but differs from the present new genus by having 3-4 acute denticles on the distal cutting edges of the tapered first pereiopodal fingers (Bruce, 1991) instead of the unarmed edges in Michaelimenes (Fig. 1A). The particular morphological structure in the first pereiopod is considered as one of the diagnostic characters for generic rank within Periclimenes and its related genera (cf. Li, 2009; Ďuriš and Horká, 2017), therefore, it is better that in time, a further new genus should be erected for P. forcipulatus.

Michaelimenes perlucidus (Bruce, 1969) n. comb. (Figs. 1-5)

Periclimenes perlucidus Bruce, 1969: 268; Bruce, 1978a: 230, figs. 12-15; Bruce, 1979: 227; De Grave, 2000: 138; Li, 2000: 224 (list) (in part); Bruce, 2003: 240 (list); De Grave and Fransen, 2011: 365 (list).

Periclimenes involens Bruce, 1996: 234, figs. 13, 28h; Li, 2000: 198 (list), fig. 251; Bruce, 2003: 236 (list); Li and Bruce, 2006: 696, fig. 22; De Grave and Fransen, 2011: 363 (list) (new synonymy, see "Remarks"). Periclimenes sp. B.- Kato and Okuno, 2001: 40, unnumbered fig. in color (see "Remarks"). 


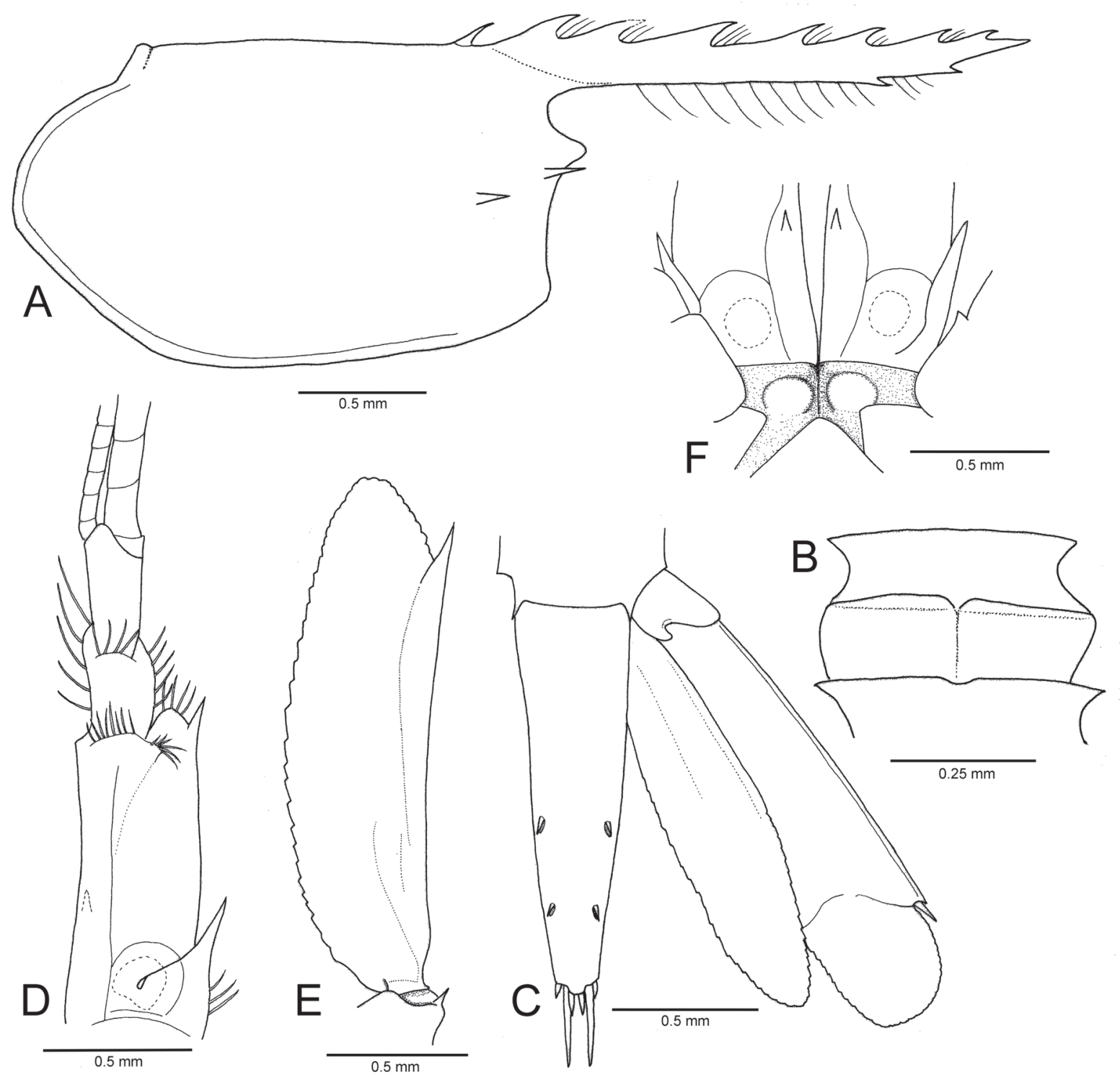

Figure 3. Michaelimenes perlucidus (Bruce, 1969), n. comb. Male, CL $1.6 \mathrm{~mm}$ (CMNH-ZC 02526). A, carapace and rostrum, lateral; $\mathrm{B}$, fourth and fifth thoracic sternites, ventral; $\mathrm{C}$, telson and right uropod, dorsal; $\mathrm{D}$, right antennular peduncle and proximal part of flagella, dorsal; E, scaphocerite and distal part of basicerite of right antenna, dorsal; F, epistomal region, ventral. C, E, setae omitted.

Material examined. Japan. Honshu. CMNH-ZC 02526, 1 đิ CL 1.6 mm, CMNH-ZC 02527, 1 ๙ CL $1.7 \mathrm{~mm}, \mathrm{CMNH}-\mathrm{ZC}$ 02528, 1 ovig. ㅇ CL $2.3 \mathrm{~mm}$,

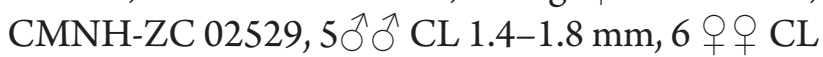
$1.2-1.8 \mathrm{~mm}, 5$ ovig. 우 우 CL 1.9-2.4 mm, 5 juveniles CL 0.8-1.1 mm, off Uki-shima Islet, Katsuyama, Kyonan, W coast of Boso Peninsula, 3506.7'N 13948.8'E, 25 m, 13 November 2016. CMNH-ZC 02501, 1 ○ CL 1.9 mm, Ose-zaki, Numazu, Suruga Bay, $35^{\circ} 02.1^{\prime} \mathrm{N} 138^{\circ} 47.3^{\prime} \mathrm{E}, 20 \mathrm{~m}$, 9 October 1996; RMNH. CRUS.D.57229, 1 ovig. + CL $2.1 \mathrm{~mm}$, same locality as CMNH-ZC 02501, 27 m, November 2001; RMNH.
CRUS.D.57230, 1 ovig. $q$ CL $2.6 \mathrm{~mm}$, same locality as CMNH-ZC 02501, $21 \mathrm{~m}$, 20 July 2003. Izu Islands. CMNH-ZC 02517, 2 ovig. 우 CL 1.9-2.0 mm, Akinohama, Izu-ohshima Island, $34^{\circ} 47.2^{\prime} \mathrm{N} 139^{\circ} 24.5^{\prime} \mathrm{E}, 40$ m, 12 January 2011; CMNH-ZC 02502, 1 \ CL 1.3 $\mathrm{mm}$, Kyokucho-hama, Hachijo-jima Island, 3309.3’ N 13946.7’E, 30 m, 2 August 1999; CMNH-ZC 02503, 1 q CL $1.6 \mathrm{~mm}$, same locality as CMNH-ZC 02502,

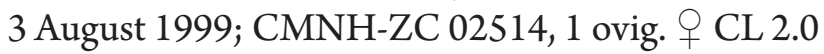
mm CL, same locality as CMNH-ZC 02502, $25 \mathrm{~m}$, 2 August 2011; CMNH-ZC 02513, 1 ○ CL $1.5 \mathrm{~mm}$, Nazumado, Hachijo-jima Island, $33^{\circ} 08.5^{\prime} \mathrm{N} 139^{\circ} 44.4^{\prime} \mathrm{E}$, 


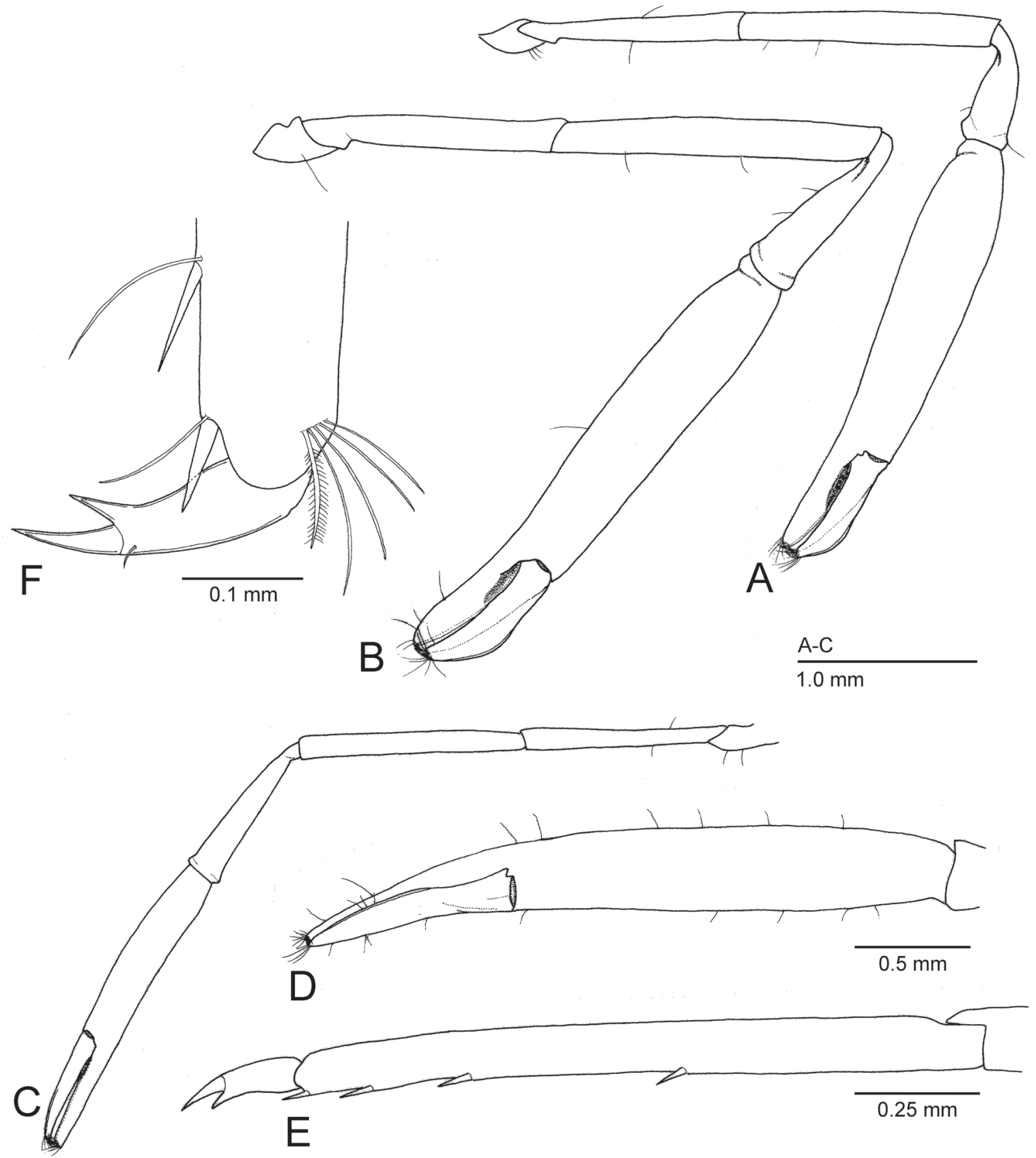

Figure 4. Michaelimenes perlucidus (Bruce, 1969), n. comb. Male, CL $1.6 \mathrm{~mm}$ (CMNH-ZC 02526) (A, C, E); male, CL $1.7 \mathrm{~mm}$ (CMNH-ZC 02527) (B); ovigerous female, CL $2.3 \mathrm{~mm}$ (CMNH-ZC 02528) (D, F). A, B, right major second pereiopod, lateral; C, left minor second pereiopod, lateral; D, same, chela, dorsal; E, left third pereiopod, propodus and dactylus, lateral (setae omitted); F, right third pereiopod, distal part of propodus and dactylus, lateral.

35 m, 4 August 2004. Ryukyu Islands. CMNH-ZC 01901, 1 ovig. क CL $2.7 \mathrm{~mm}$, Hoshu, Onna Village, Okinawa-jima Island, $26^{\circ} 30.2^{\prime} \mathrm{N} 127^{\circ} 50.7^{\prime} \mathrm{E}, 42 \mathrm{~m}, 5$ May 2005.

Host. Alcyonacean species belonging to Chironephthya Studer, 1887 (Cnidaria: Anthozoa:
Octocorallia: Alcyonacea: Nidaliidae).

Holotype. Ovigerous + , CL $2.13 \mathrm{~mm}$ (examined by C.H.J.M. Fransen), RMNH.CRUS.D.47760.

Distinguishing features. Small-sized, typical palaemonid form with slender ambulatory pereiopods (Fig. 2). 


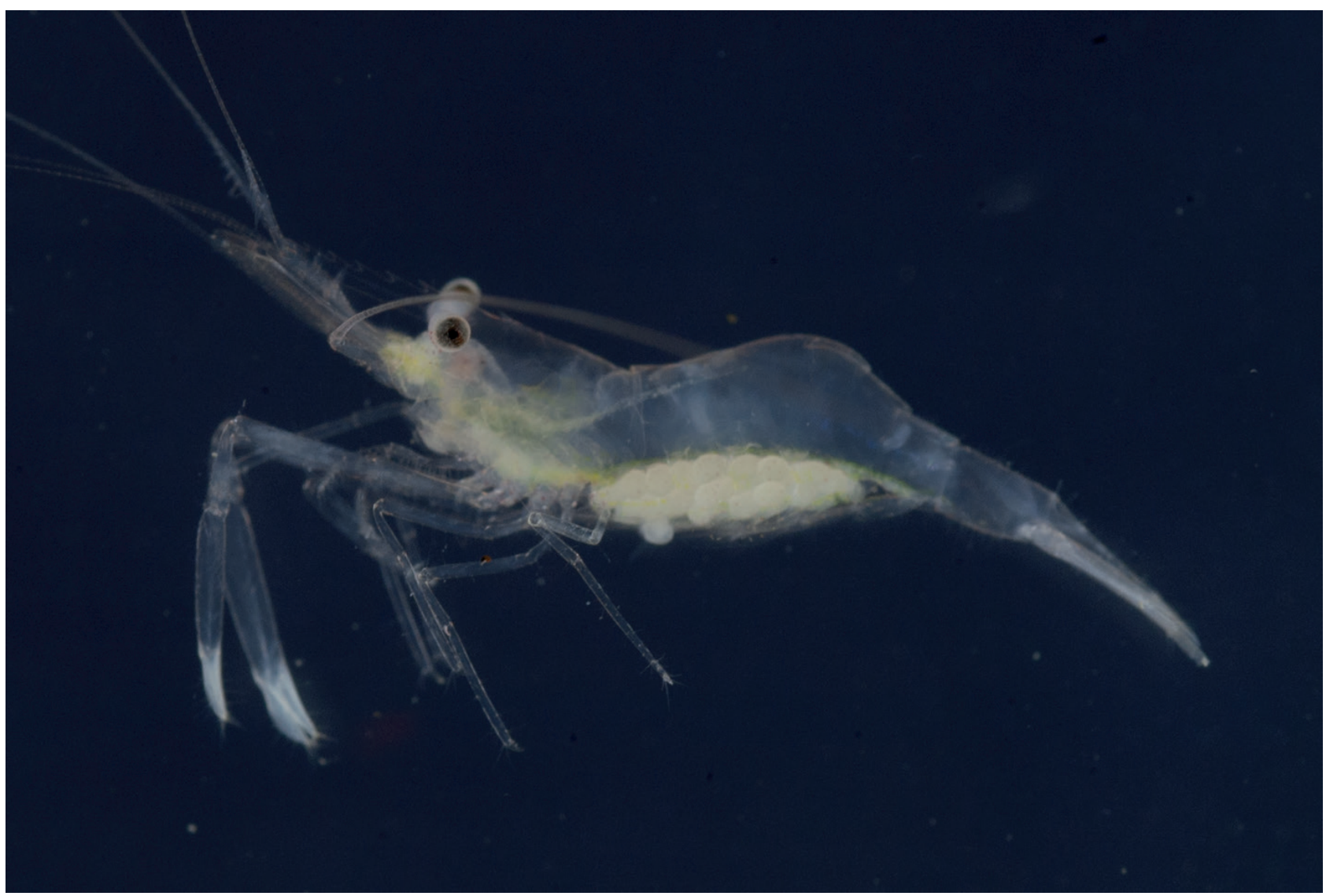

Figure 5. Michaelimenes perlucidus (Bruce, 1969), n. comb. Ovigerous female, CL 2.3 mm (CMNH-ZC 02528). Fresh specimen, lateral.

Carapace (Fig. 3A), smooth, glabrous, without supraorbital spine; orbit feebly developed, inferior orbital angle produced, tip rounded; antennal spine marginal, reaching level of tip of inferior orbital angle; hepatic spine slightly ventrad to antennal spine; epigastric spine situated anterior fourth of median carina, separated from first rostral tooth by almost same gap as between first and second dorsal teeth. Rostrum (Fig. 3A) straight, horizontal, slightly overreaching level of distal margin of antennular distal segment (Fig. 2), 1.0-1.3 times as long as carapace; dorsal carina armed with 6-8 equidistant teeth, first tooth situated just above posterior orbital margin; ventral margin straight, carina obsolete, armed with 1-3 teeth on distal third.

Ophthalmic somite without interocular beak. Fourth thoracic sternite (Fig. 3B) with low, transverse central ridge with median small notch, lacking fingerlike median process. Sixth abdominal segment (Fig. 2) stout, moderately short, 0.7-0.9 times as long as telson. Telson (Fig. 3C) slightly tapering distally, with two pairs of small dorsolateral spines situated on posterior half, posterior margin with three pairs of spines.

Antennular peduncle (Fig. 3D) with proximal segment armed ventromesially with a single acute tooth; lateral margin straight, terminating distally in acute tooth; stylocerite acute, reaching proximal two fifths of proximal segment. Antenna with scaphocerite (Fig. 3E) well developed, lateral margin terminating in acute tooth falling short of bluntly angulate distal margin of lamella. Epistome (Fig. 3F) with a pair of rounded, low, submedian eminences.

First pereiopod overreaching level of distal margin of scaphocerite by length of dactylus; cutting edges of both fingers unarmed, dactylus not subspatulate (Fig. 1A). Second pereiopods unequal in length, dissimilar in shape. Major second pereiopod (Fig. 4A, B) overreaching level of distal margin of scaphocerite by lengths of chela and part of carpus; carpus usually short (Fig. 4A) (rarely slightly elongate as in Fig. 4B), feebly widening distally, $0.2-0.4$ (usually 0.3 ) times as long as chela; chela with palm stout, elongate, subcylindrical, surface smooth, 2.4-3.1 times as long as dactylus, 
fingers short, slightly sinuous laterally; fixed finger with proximal excavation on the cutting surface (Fig. 1B) for reception of proximal part of dactylar cutting edge, proximal part of cutting edge armed with 3-4 teeth, anterior tooth largest, triangular (Fig. 1C, D); dactylus with distinct dorsomesial flange on distal two thirds, mesial surface ventrad to the flange oblique, cutting edge armed proximally with 2 triangular teeth (Fig. 1C). Minor pereiopod (Fig. 4C) overreaching level of distal margin of scaphocerite by length of chela; carpus moderately elongate, $0.2-0.4$ times as long as chela; chela with palm slender, elongate, subcylindrical, surface smooth (Fig. 4D), 1.4-2.6 times as long as dactylus, fingers somewhat elongate, slightly sinuous laterally; fixed finger with proximal excavation similar to major pereiopod, cutting edge armed proximally with 2-4 teeth (rarely unarmed), anterior tooth largest, triangular (Fig. 1E); dactylus with feeble distomesial flange on distal two thirds (Fig. 4D), cutting edge armed proximally with 1-2 triangular teeth (rarely unarmed) (Fig. 1E).

Ambulatory pereiopods similar to each other. Propodi armed with 4 small spines ventrally, without rows of tuft of long setae (Fig. 4E). Dactyli (Fig. 4F) biunguiculate, terminal unguis demarcated, distinctly longer and stouter than preterminal unguis.

Endopod of male first pleopod oblong, distally rounded, mesially with slender process. Endopod of male second pleopod with appendices masculina and interna, the former falling short of tip of the latter.

Color in life. Body and appendages generally translucent; anterior to ventral margin of carapace and ventral margins of abdominal somites bright yellow; antennal basicerite yellow (Fig. 5).

Distribution. Type locality: Macclesfield Bank, South China Sea, $16^{\circ} 06.5^{\prime} \mathrm{N} 114^{\circ} 38.3^{\prime} \mathrm{E}-16^{\circ} 05.8^{\prime} \mathrm{N}$ $114^{\circ} 38.2^{\prime} \mathrm{E}, 78.7-80.5 \mathrm{~m}$ depth (Bruce, 1969). Also known from Madagascar, La Réunion, Papua New Guinea, Philippines and Japan (Bruce, 1978a, 1996; De Grave, 2000; Kato and Okuno, 2001; Li and Bruce, 2006; present study). Bathymetrically known from 20 to $110 \mathrm{~m}$. Boso Peninsula of Japan is the northernmost record in its known range.

Common name. Yaiba-kakure-ebi (new standard Japanese name).
Remarks. Bruce (1969) originally described $P$. perlucidus on the basis of a single ovigerous female holotype collected from the South China Sea. Although no illustration was provided in the original description, subsequently, the original author re-described and fully illustrated $P$. perlucidus based on numerous specimens from Madagascar, western Indian Ocean (Bruce, 1978a). As a result of the comparison with these previous studies, the present specimens from Japan can be identified as M. perlucidus on account of the straight and horizontal rostrum armed dorsally with 6-8 teeth and ventrally with $2-3$ teeth (Fig. 3A), the remarkably unequal second pereiopods in size and shape (Fig. 3A, C), the dactylus of the major second pereiopod with a distinct flange dorsomesially (Fig. 1C, D), and the biunguiculate dactyli of the ambulatory pereiopods (Fig. 4F). Although Bruce (1969) did not allude to the length of the dorsal flange of the major second pereiopodal dactylus, the holotype of $P$. perlucidus has it on the distal two thirds of the dactylar length as depicted in the present study (Fig. 1C, D) (C.H.J.M. Fransen, in litt.). Some minor morphological differences exist between the present specimens and previous reports as mentioned below. I consider these gaps to be intraspecific variation. All the Japanese specimens possess an epigastric spine, and have the hepatic spine situated at a lower level than the antennal spine (Fig. 3A) as in the holotype (Bruce, 1969). The specimens from Madagascar reported upon Bruce (1978a), however, show variation in the absence or presence of the epigastric spine, and have the hepatic spine situated at the same level as the antennal spine. The carpus of the major second pereiopod is short in most of the present specimens (Fig. 4A), but some of the examined specimens possess a relatively slender carpus being over one third of the length of the chela (Fig. 4B), the proportion of which corresponds to the original description. In the herein examined specimens, the palm of the second pereiopod is 2.4-3.1 times as long as the dactylus, instead of 4.0 times in the holotype and 2.3 times in the specimens from Madagascar (Bruce, 1969; 1978a).

Bruce (1996) described $P$. involens as a new species on the basis of 1 male and 3 female specimens from the depths of 92-97 m off Mindoro, Philippines. This species has also been recorded from La Réunion, western Indian Ocean by Li and Bruce (2006). 
In the original description, Bruce (1996) compared P. involens with Periclimenes vaubani Bruce, 1990 and Periclimenes richeri Bruce, 1990, described from considerably deeper waters at 445-650 $\mathrm{m}$ in New Caledonian waters (Bruce, 1990). However, P. involens appears closest to $M$. perlucidus rather than $P$. vaubani and P. richeri on account of the form of the rostrum and the development of the dorsal flange of the dactylus and the proximal excavation of the fixed finger in the major second pereiopod. The present study reveals that the proportion of the major second pereiopod is intraspecifically variable within $M$. perlucidus, and that of $P$. involens is closely similar to the typical form of the present specimens of M. perlucidus (Fig. 4A). Therefore, $P$. involens is considered a synonym of $M$. perlucidus.

The host of the P. perlucidus holotype was indicated as "gorgonian" in the original description (Bruce, 1969). Later, Bruce (1978a; 1979) identified the host as Verrucella sanguinolenta (Gray) (Octocorallia: Alcyonacea: Ellisellidae, now called as Phenilia sanguinolenta Gray, 1859). In addition, Bruce (1978a) listed three species of soft corals included in the family Nephtheidae, viz., Roxasia speciosa (Kükenthal), Morchellana gilva (Henderson), and Morchellana nova Tixier Durivault. The valid names of the former two species are now applied as Dendronephthya speciosa Kükenthal, 1905 and Dendronephthya gilva Henderson, 1909 respectively, and Morchellana nova sensu Bruce (1978a) possibly belongs to the same taxon as Dendronephthya novaezeelandiae Kükenthal, 1905 since the specific name "nova" is not known for any species of alcyonacean (Yukimitsu Imahara, in litt.). Furthermore, De Grave (2000) indicated the host of P. perlucidus from Hansa Bay, Papua New Guinea as Dendronephthya sp. From these previous records, the preferred hosts of $M$. perlucidus appear to be species of the genus Dendronephthya Kükenthal, 1905, and $P$. sanguinolenta is possibly considered as an alternative host. Therefore, Chironephthya spp. associated with the present specimens examined represents a new host record. In Japanese waters, the relationship between $M$. perlucidus and Dendronephthya has not been observed, nevertheless colonies of Dendronephthya are abundant at the collection sites of the present shrimp specimens. A hypothesis for this host selection seems to be that the relationship appeared only in the warm temperate waters of the Western Pacific. More observations from other areas in the Indo-West Pacific are required to be more conclusive with regards to the host specificity of M. perlucidus.

The color pattern of $M$. perlucidus has only been previously recorded by De Grave (2000) as "transparent with a yellow hue". The coloration of the present specimens agrees with this indication on account of the transparent body and appendages and yellow markings on the anterior and ventral margin of the carapace and ventral margins of the abdominal somites (Fig. 5). This color pattern is characteristic, and differs from other palaemonid shrimp species associated with alcyonaceans. In the popular guidebook on the decapod and stomatopod crustaceans from Hachijojima Island, Japan, Kato and Okuno (2001) reported a palaemonid shrimp associated with Chironephthya sp. under the name of "Periclimenes sp. B". Although a voucher specimen was not collected, the color pattern of the photographed individual corresponds to those of the specimens examined in this study, and part of these were captured from the same island. Therefore, Periclimenes sp. B sensu Kato and Okuno (2001) can be identified without hesitation as M. perlucidus.

Fransen (1994) reported two male and two ovigerous female specimens of $P$. perlucidus from the Seychelles, western Indian Ocean. However, the illustrated male and female have the symmetrical and slender second pereiopods as in the minor pereiopod of the Madagascar specimens reported upon by Bruce (1978a). The examined specimens from Japan contain the similar sized individuals to the Fransen's (1994) specimens, and showed the markedly unequal second pereiopods and the distinct flange on the dactylus of the major pereiopod. Thus, I consider the specimens from the Seychelles being a species outside of Michaelimenes.

\section{ACKNOWLEDGEMENTS}

I wish to express my sincere gratitude to Jiro Uochi of Kacchama Diving Survice, and Koichiro Hirashima of Kyonan-Katsuyama Fishery Association, for their help in capturing the present specimens at Ukishima Islet, off Katsuyama, Boso Peninsula, Japan. I am indebted to Osamu Hoshino of Izu-ohshima Island, Kotaro Tanaka of Hachijo-jima Island and Tohru Yanagisawa of Arakawa-ku, Tokyo, for donating to me some specimens. My thanks go to Charles H.J.M. Fransen of the Naturalis Biodiversity Center, 
Leiden, for important information of the holotype of Periclimenes perlucidus, and Yukimitsu Imahara of the Wakayama Laboratory, Biological Institute on Kuroshio, for valuable information on the valid names of octocorallian hosts. I deeply thank Sammy De Grave of the Oxford University Museum of Natural History, Zdeněk Duriš of the University of Ostrava, and C.H.J.M. Fransen for reviewing the manuscript and offering valuable comments for improvements.

\section{ReferenCes}

Bruce, A.J. 1969. Preliminary descriptions of sixteen new species of the genus Periclimenes Costa, 1844 (Crustacea, Decapoda, Natantia, Pontoniinae). Zoologische Mededelingen, 43: 253278.

Bruce, A.J. 1978a. A report on a collection of pontoniine shrimps from Madagascar and adjacent seas. Zoological Journal of the Linnean Society, 62: 205-290.

Bruce, A.J. 1978b. The re-examination of some pontoniine shrimp types first described by L. A. Borradaile (Decapoda, Palaemonidae). Crustaceana, 34: 251-268.

Bruce, A.J. 1979. Records of some pontoniine shrimps from the South China Sea. Cahiers l'Indo-pacifique, 1: 215-248.

Bruce, A.J. 1980. Periclimenes carinidactylus Bruce, a crinoidassociated pontoniine shrimp, from South Australia. Crustaceana, 38: 295-305.

Bruce, A.J. 1989. Periclimenes gonioporae sp. nov. (Crustacea: Decapoda: Palaemonidae), a new coelenterate-associated shrimp. The Beagle, Records of the Northern Territory Museum of Arts and Sciences, 6: 149-156.

Bruce, A.J. 1990. Crustacea Decapoda: Deep-sea palaemonid shrimps from New Caledonian Waters. In: A. Crosnier (ed), Résultats des campagnes MUSORSTOM, Volume 6. Mémoires du Muséum national d'Histoire naturelle, Paris, (Zoologie), 145: 149-215.

Bruce, A.J. 1991. Crustacea Decapoda: Further deep-sea palaemonid shrimps from New Caledonian Waters. In: A. Crosnier (ed), Résultats des campagnes MUSORSTOM, Volume 9. Mémoires du Muséum national d'Histoire naturelle, Paris, (Zoologie), 152: 299-411.

Bruce, A.J. 1996. Crustacea Decapoda: Palaemonid shrimps from the Indo-West Pacific region mainly from New Caledonia. In: A. Crosnier (ed), Résultats des campagnes MUSORSTOM, Volume 15. Mémoires du Muséum national d'Histoire naturelle, Paris, (Zoologie), 168: 197-267.

Bruce, A.J. 2003. The pontoniine shrimp fauna of Hong Kong and the South China Sea (Crustacea: Decapoda: Palaemonidae). p. 209-257. In: B. Morton (ed), Perspective on Marine Environment Change in Hong Kong and South China Sea, 1977-2001. Proceedings of an International Workshop Reunion Conference, Hong Kong 21-26 October 2001. Hong Kong, Hong Kong University Press.

De Grave, S. 2000. Caridean shrimps (Crustacea, Decapoda) from Hansa Bay, Papua New Guinea: Palaemonidae and Gnathophyllidae. Bulletin de l'Institut Royal des Sciences Naturelles de Belgique, Biologie, 70: 119-148.
De Grave, S. and Anker, A. 2009. A new species of Periclimenes Costa from Utila, Honduras (Crustacea, Decapoda, Pontoniinae). Annalen des Naturhistorischen Museums in Wien, 110: 139-148.

De Grave, S. and Fransen, C.H.J.M. 2011. Carideorum catalogus: The Recent species of the dendrobranchiate, stenopodidean, procarididean and caridean shrimps (Crustacea: Decapoda). Zoologische Mededelingen, 85: 195-589.

Ďuriš, Z. and Horká, I. 2017. Towards a revision of the genus Periclimenes: resurrection of Ancylocaris Schenkel, 1902, and designation of three new genera (Crustacea, Decapoda, Palaemonidae). Zookeys, 646: 25-44.

Eilbracht, J. and Fransen, C.H.J.M. 2015. Periclimenes machrorhynchia sp. nov., a new hydrozoan-associated pontoniine shrimp (Crustacea, Decapoda, Palaemonidae) from North East Kalimantan, Indonesia. Zootaxa, 3994: 377-395.

Fransen, C.H.J.M. 1994. Marine palaemonid shrimps of the Netherlands Seychelles Expedition 1992-1993. Zoologische Verhandelingen, 297: 85-152.

Gan, Z.B.; Li, X.Z.; Chan, T.-Y.; Chu, K.H. and Kou, Q. 2015. Phylogeny of Indo-West Pacific pontoniine shrimps (Crustacea: Decapoda: Caridea) based on multilocus analysis. Journal of Zoological Systematics and Evolutionary Research, 53: 282-290.

Grippa, G.B. and Udekem d'Acoz, C. d'. 1996. The genus Periclimenes Costa, 1844 in the Mediterranean Sea and the Northeastern Atlantic Ocean: review of the species and description of Periclimenes sagittifer aegylios subsp. nov. (Crustacea, Decapoda, Caridea, Pontoniinae). Atti della Società italiana di Scienze naturali e del Museo Civico di Storia natural di Milano, 135: 401-412.

Hayashi, K.-I. 2005. Prawns, Shrimps and Lobsters from Japan (140). Family Palaemonidae, Subfamily Pontoniinae-Genus Periclimenes 6. Aquabiology, 27: 161-168. (In Japanese)

Holthuis, L.B. 1951. A general revision of the Palaemonidae (Crustacea Decapoda Natantia) of the Americas, I: The subfamilies Euryrhynchinae and Pontoniinae. Allan Hancock Foundation Publications, Occasional Paper, 11: 1-332, pls.1-63.

Horká, I.; De Grave, S.; Fransen, C.H.J.M.; Petrusek, A. and Ďuriš, Z. 2016. Multiple host switching events shape the evolution of symbiotic palaemonid shrimps (Crustacea: Decapoda). Scientific Reports, 6: 26486. http//dx.doi.org/10.1038/ srep 26486

Kato, S. and Okuno, J. 2001. Shrimps and crabs of Hachijo Island; p. 157. Tokyo, TBS-Britannica. (In Japanese)

Kemp, S. 1922. Notes on Crustacea Decapoda in the Indian Museum. XV. Pontoniinae. Records of the Indian Museum, 24: 113-288, pls. 3-9.

Kou, Q.; Li, X., and Bruce, A.J. 2016. Designation of a new genus Bathymenes for the deep-sea pontoniine shrimps of the 'Periclimenes alcocki species group' (Decapoda, Caridea, Palaemonidae), with the checklist of the species assigned to the genus. Chinese Journal of Oceanology and Limnology, 34: 170-176.

Li, X. 2000. Catalog of the genera and species of Pontoniinae Kingsley, 1878 (Decapoda, Palaemonidae). Beijing, Xueyuan Press, 319p.

Li, X. 2008. Report on some species of Palaemonidae (Crustacea, Decapoda) from French Polynesia. Zoosystema, 30: 203-252. 
Li, X. 2009. Sandimenes nov. gen. for Periclimenes hirsutus Bruce, 1971 (Decapoda, Caridea, Pontoniinae). Crustaceana, 82: 881-896.

Li, X. and Bruce, A.J. 2006. Further Indo-West Pacific palaemonid shrimps (Crustacea: Decapoda: Palaemonidae), principally from the New Caledonian region. Journal of Natural History, 40: 611-738.

Marin I.H. and Chan, T.-Y. 2014. Deep water echinoid-associated pontoniine shrimp "Periclimenes hertwigi Balss, 1913 species group" (Crustacea: Decapoda: Caridea: Palaemonidae): species review, description of a new genus and species from Philippines. Zootaxa, 3835: 301-324.

Okuno, J. and Bruce, A.J. 2010. Designation of Ancylomenes gen. nov., for the 'Periclimenes aesopius species group' (Crustacea: Decapoda: Palaemonidae), with the description of a new species and a checklist of the congeneric species. In: S. De Grave and C.H.J.M. Fransen (eds), Contributions to shrimp taxonomy. Zootaxa, 2372: 85-105. 